\title{
Cardiac Surgery Increases Serum Concentrations of Adipocyte Fatty Acid-Binding Protein and Its mRNA Expression in Circulating Monocytes but Not in Adipose Tissue
}

\author{
T. KOTULAK ${ }^{1}$, J. DRAPALOVA ${ }^{2}$, M. LIPS ${ }^{3}$, Z. LACINOVA ${ }^{2}$, P. KRAMAR $^{1}$, H. RIHA $^{1}$, \\ I. NETUKA ${ }^{4,5}$, J. MALY ${ }^{4}$, J. BLAHA ${ }^{3}$, J. LINDNER ${ }^{5}$, S. SVACINA $^{2}$, M. MRAZ ${ }^{2}$, \\ M. HALUZIK ${ }^{2}$
}

${ }^{1}$ Department of Anesthesia and Resuscitation, Institute for Clinical and Experimental Medicine, Prague, Czech Republic, ${ }^{2}$ Third Department of Medicine, First Faculty of Medicine, Charles University and General University Hospital, Prague, Czech Republic, ${ }^{3}$ Department of Anesthesia, Resuscitation and Intensive Medicine, First Faculty of Medicine, Charles University and General University Hospital, Prague, Czech Republic, ${ }^{4}$ Department of Cardiovascular Surgery, Institute for Clinical and Experimental Medicine, Prague, Czech Republic, ${ }^{5}$ Second Department of Surgery, Department of Cardiovascular Surgery, First Faculty of Medicine, Charles University in Prague, Prague, Czech Republic

Received May 22, 2013

Accepted August 21, 2013

On-line November 1, 2013

\section{Summary}

Adipocyte fatty acid binding protein (A-FABP) is a novel adipokine involved in the regulation of lipid and glucose metabolism and inflammation. To evaluate its potential role in the development of postoperative hyperglycemia and insulin resistance we assessed A-FABP serum concentrations and mRNA expression in skeletal and myocardial muscle, subcutaneous and epicardial adipose tissue and peripheral monocytes in 11 diabetic and 20 age- and sex-matched non-diabetic patients undergoing elective cardiac surgery. Baseline serum A-FABP did not differ between the groups ( $31.1 \pm 5.1$ vs. $25.9 \pm 4.6 \mathrm{ng} / \mathrm{ml}, \mathrm{p}=0.175$ ). Cardiac surgery markedly increased serum A-FABP in both groups with a rapid peak at the end of surgery followed by a gradual decrease to baseline values during the next $48 \mathrm{~h}$ with no significant difference between the groups at any timepoint. These trends were analogous to postoperative excursions of plasma glucose, insulin and selected proinflammatory markers. Cardiac surgery increased A-FABP mRNA expression in peripheral monocytes, while no effect was observed in adipose tissue or muscle. Our data suggest that circulating A-FABP might be involved in the development of acute perioperative stress response, insulin resistance and hyperglycemia of critically ill irrespectively of the presence of diabetes mellitus.

\section{Key words}

Adipocyte fatty acid binding protein - Adipose tissue - Skeletal muscle • Cardiac surgery $\bullet$ Insulin resistance

\section{Corresponding author}

Martin Haluzik, $3^{\text {rd }}$ Department of Medicine, $1^{\text {st }}$ Faculty of Medicine, Charles University, U Nemocnice 1, 12808 Prague 2, Czech Republic. Fax: +420-224919780. E-mail: mhalu@lf1.cuni.cz

\section{Introduction}

Adipocyte fatty acid binding protein (A-FABP) also known as FABP4, aP2 or adipocyte/macrophage FABP is a cytoplasmic protein found abundantly in adipose tissue (Hunt et al. 1986). A-FABP is predominantly expressed in adipocytes (Baxa et al. 1989) and macrophages (Boord et al. 2002). A-FABP was primarily described as a mostly cytosolic protein constituting $6 \%$ of total adipocyte cellular protein content and partially released into circulation. Experimental and clinical studies have suggested that AFABP plays a role in the regulation of lipid and glucose metabolism, energy homeostasis and inflammation 
(Furuhashi et al. 2008, Hotamisligil et al. 1996, Uysal et al. 2000, Xu et al. 2006). In mice, increased production of both adipocyte and macrophage FABP contributes to metabolic deterioration (Furuhashi et al. 2008). Deletion of A-FABP in adipocytes resulted in reduced expression of proinflammatory cytokines in macrophages, while its deletion in macrophages enhanced insulin signaling and glucose uptake in adipocytes (Furuhashi et al. 2008). AFABP deficient mice with genetic or diet induced obesity were protected from insulin resistance, dyslipidemia and hyperglycemia (Hotamisligil et al. 1996, Uysal et al. 2000). In humans, the reduction of adipose tissue AFABP expression due to a specific polymorphism of the aP2 gene resulted in lower serum triglyceride levels and significantly reduced the risk of coronary heart disease and type 2 diabetes mellitus (Tuncman et al. 2006). Serum levels of A-FABP were closely associated with the presence and severity of coronary artery disease (Bao et al. 2011, Doi et al. 2011). In contrast, A-FABP levels in chronically malnourished patients with anorexia nervosa were unchanged and were not related to anthropometric or inflammatory parameters (Haluzikova et al. 2009). Serum A-FABP concentrations were significantly higher in females compared to males and were independently associated with waist-to-height ratio and glomerular filtration rate (Tonjes et al. 2012). In another study on 495 non-diabetic Chinese adults, elevated plasma concentrations of A-FABP predicted the development of metabolic syndrome in a 5-year follow-up (Xu et al. 2007).

A large number of clinical studies have documented the presence of hyperglycemia and insulin resistance in critically ill patients (Van den Berghe 2002) with a couple of recent trials indicating beneficial effects of improved glucose control after continuous intravenous insulin treatment on allover morbidity and mortality associated with critical illness. Conflicting data exist regarding optimal target glucose range in different types of patients (Van den Berghe et al. 2001, Finfer et al. 2009, Blaha et al. 2009). The etiopathogenesis of insulin resistance in critically ill patients differs in part from subjects with type 2 diabetes mellitus. Nevertheless, common mechanisms still exist including the development of liver insulin resistance and overproduction of proinflammatory factors by adipose tissue (Kremen et al. 2006, Mazurek et al. 2003). In a recent study on different experimental models with biologically active synthetic A-FABP inhibitor, the authors demonstrated its potential beneficial effects on insulin resistance, glucose control, circulating lipid levels and development of atherosclerosis (Furuhashi et al. 2007) suggesting its potential use in various patient populations suffering from insulin resistance, hyperglycemia and its consequences. We hypothesized that A-FABP may also play a role in the development of hyperglycemia and insulin resistance in patients undergoing elective cardiac surgery. To this end, we measured A-FABP mRNA expression in epicardial and subcutaneous adipose tissue and myocardial and skeletal muscle of patients undergoing elective cardiac surgery and studied its serum changes both during and after the surgery. The secondary objective of our study was to analyze the influence of type 2 diabetes mellitus on serum A-FABP and its mRNA expression in critically ill cardiosurgical patients.

\section{Methods}

\section{Study subjects}

The study included 31 male patients who underwent elective cardiac surgery with extracorporeal circulation (coronary artery bypass grafting (CABG) 23 patients, CABG and aortic valve replacement (AVR) 4 patients, AVR alone - 1 patient, mitral valve replacement (MVR) - 2 patients and CABG and MVR 1 patient). Average surgery time was 308 minutes. Eleven subjects had type 2 diabetes mellitus (T2DM) treated by metformin ( 2 patients), insulin (5 patients) or diet only (4 patients). All patients participating in the study had arterial hypertension, ischemic heart disease and body mass index $(\mathrm{BMI}) \geq 25$. None of the patients had diagnosis or suffered from acute or chronic kidney disease, malignancy, thyroid disease, or acute infection. Thirteen patients had hyperlipidemia treated by atorvastatin (10 patients), rosuvastatin (1 patient) or fluvastatin (2 patients), respectively.

All patients ate the last meal at $6 \mathrm{PM}$ on the day before the surgery. The surgery was performed after an overnight fasting and was started between 7-8 AM in all subjects.

Ten patients received infusion of dobutamine and norepinephrine during and after surgery with maximum dose of $7 \mu \mathrm{g} / \mathrm{kg} / \mathrm{min}$ and $0.2 \mu \mathrm{g} / \mathrm{kg} / \mathrm{min}$, respectively with treatment duration from 8 to $33 \mathrm{~h}$. Glucose infusion was not administered in any of the patients.

All participants signed written informed consent prior to the enrollment into the study. The study was 
approved by the Human Ethical Review Board of the Thomayer University Hospital and Institute for Clinical and Experimental Medicine, Czech Republic and was performed in accordance with the guidelines proposed in the Declaration of Helsinki.

\section{Glucose control protocol and insulin administration}

Undiluted arterial blood for measurement of blood glucose (BG) was drawn from an arterial line inserted for routine monitoring procedures. BG was analyzed by a standard point-of-care testing device (Abbott Architect CI 8200, Abbott Diagnostics, Maidenhead, U.K.) every $3 \mathrm{~h}$.

No glucose infusion was administered in any of the patients during the study. No insulin was administered during the operation. Insulin administration was initiated in postoperative intensive care unit only in patients with blood glucose exceeding $9.9 \mathrm{mmol} / \mathrm{l}$ (in 17 patients altogether - 11 with and 6 without T2DM). Human rapid-acting insulin (Actrapid HM, Novo Nordisk, Baegsvard, Denmark) was given via central venous line as a continuous infusion. A standard concentration of $50 \mathrm{IU}$ of insulin in $50 \mathrm{ml}$ of $0.9 \% \mathrm{NaCl}$ was used. Target glucose range was 6.0-9.9 $\mathrm{mmol} / 1$. Normal oral food intake was started in 18 to $24 \mathrm{~h}$ after the operation in all study subjects.

\section{Anthropometric examination, blood and tissue sampling}

Anthropometric examination of study subjects was performed at baseline one day prior to the operation. All subjects were measured and weighted in light clothes without shoes using standardized scales and BMI was calculated. Body surface area was calculated using the DuBois and DuBois formula. Waist circumference was measured. The same study nurse did all anthropometric measurements in a standardized way. Blood samples for hormonal measurements were taken prior to initiation of anesthesia (baseline), prior to the start of extracorporeal circulation, upon completion of the operation and 6,24 , 48 , and $96 \mathrm{~h}$ after the end of the operation. Serum was obtained by centrifugation and the samples were subsequently stored in aliquots at $-80^{\circ} \mathrm{C}$ until further analysis. In a subgroup of 11 patients blood samples for monocyte isolation were obtained in Na-EDTA anticoagulant at the start and upon completion of the surgery and $24 \mathrm{~h}$ after the end of the surgery.

Samples of subcutaneous (thoracic region) and visceral (epicardial) adipose tissue, skeletal muscle (intercostal muscles) and myocardial muscle (right atrium) for mRNA expression analysis were taken at the start and prior to the end of the surgery from approximately the same location in all patients. The samples were obtained from tissues that had not been previously traumatized mechanically or by cauterization in order to avoid the interference of local damage with tissue parameters. Tissue samples were collected to $1 \mathrm{ml}$ of RNAlater reagent (Qiagen $\mathrm{GmbH}$, Hilden, Germany) and stored at $-80^{\circ} \mathrm{C}$ until further analysis. The average time between the initial and final sampling at the end of the operation was $308 \mathrm{~min}$.

\section{Hormonal and biochemical assays}

Serum levels of A-FABP were measured using a commercial ELISA kit (BioVendor, Modrice, Czech Republic) with a sensitivity of $0.1 \mathrm{ng} / \mathrm{ml}$. The intra- and inter-assay variability of the kit was less than $7 \%$. Serum C-reactive protein (CRP) levels were measured by high sensitive assay (Bender Medsystems, Vienna, Austria) with a sensitivity of $3 \mathrm{pg} / \mathrm{ml}$. The intra- and inter-assay variability of the kit was less than $5 \%$ and less than $10 \%$, respectively. Serum insulin concentrations were measured by a commercial RIA kit (Cis Bio International, Gif-sur-Yvette, France) with a sensitivity of $2.0 \mu \mathrm{IU} / \mathrm{ml}$ and the intra- and inter-assay variability of the kit was less than $5 \%$ and less than $10 \%$, respectively.

Serum concentrations of interleukin-6 (IL-6), interleukin-8 (IL-8) and monocyte chemotactic protein-1 (MCP-1) were measured using Human serum adipokine LINCOplex Kit (panel B) on a Luminex200 instrument (Linco Research, St. Charles, MO, USA). Sensitivity was $1.6 \mathrm{pg} / \mathrm{ml}$ for IL-6, $0.2 \mathrm{pg} / \mathrm{ml}$ for IL-8 and $0.14 \mathrm{pg} / \mathrm{ml}$ for MCP-1, respectively. Intra- and inter-assay variability of the kits was $7.8 \%$ and $18 \%$ for IL-6, $7.9 \%$ and $15 \%$ for IL- $8,7.8 \%$ and $16 \%$ for MCP-1, respectively.

\section{Monocyte separation from whole blood}

Peripheral blood leukocytes were obtained from blood samples using Ficoll-Paque Plus (Amersham Biosciences AB, Sweden). For each sample, $5 \mathrm{ml}$ of blood were slowly added into the Falcon tube with $3.5 \mathrm{ml}$ of Ficoll-Paque ${ }^{\mathrm{TM}}$ Plus and the tube was centrifuged immediately. After centrifugation, leukocyte agglomerates were placed in a tube containing $10 \mathrm{ml}$ of PBS (0.01 M PBS), pH 7.4 and centrifuged again, the supernatant was discarded, and the cell pellet was dissolved in PBS. After centrifugation the supernatant was discarded and the pellet was dissolved in DEGAS buffer (0.01 M PBS with $0.5 \mathrm{M}$ EDTA, pH 8 and $1 \%$ 
BSA). Magnetic activated cell sorting technique (MiniMacs Miltenyi Biotec, Bergisch Gladbach, Germany) using microbeads coated with CD14 antibody (MACS CD14 MicroBeads; Miltenyi Biotec) was used to isolate monocytes from cell pellet.

\section{Determination of A-FABP mRNA expression}

Tissue samples were homogenized on a MagNA Lyser Instrument using MagNA Lyser Green Beads (Roche Diagnostics GmbH, Mannheim, Germany) and QIAzol Lysis Reagent (Qiagen GmbH, Hilden, Germany). Total RNA was extracted from the homogenized sample of subcutaneous and epicardial adipose tissue using RNeasy Lipid Tissue Mini Kit (Qiagen GmbH, Hilden, Germany). Total RNA from the homogenized skeletal muscle and isolated monocytes was extracted on MagNA Pure instrument using MagNA Pure Compact RNA Isolation (Tissue) kit (Roche Diagnostics GmbH, Mannheim, Germany). RNA concentration was determined from absorbance at $260 \mathrm{~nm}$ on a BioPhotometer (Eppendorf AG, Hamburg, Germany). The integrity of the RNA was checked by visualization of $18 \mathrm{~S}$ and $28 \mathrm{~S}$ ribosomal bands on $1 \%$ agarose gel with ethidium bromide. Reverse transcription was performed using $0.25 \mu \mathrm{g}$ of total RNA to synthesize the first strand cDNA using the random primers as per the instructions of the High-Capacity cDNA Reverse Transcription Kit (Applied Biosystems, Foster City, CA, USA). Measurements of A-FABP gene expression were performed on an ABI PRISM 7500 instrument (Applied Biosystems, Foster City, CA, USA) using TaqMan ${ }^{\circledR}$ Universal PCR Master Mix, NO AmpErase ${ }^{\circledR}$ UNG and specific TaqMan ${ }^{\circledR}$ Gene Expression Assays (Applied Biosystems, Foster City, CA, USA) and nuclease-free water (Fermentas Life Science, Vilnius, Lithuania). Controls with no template cDNA were performed with each assay and all samples were run in duplicate at a minimum. The increase in fluorescence was measured in real time and threshold cycle $\left(\mathrm{C}_{\mathrm{T}}\right)$ values were obtained. To compensate for variations in the amount of RNA used and the variable efficiency of reverse transcription, the target gene $\mathrm{Ct}$ number was normalized to the endogenous control beta-2-microglobulin (B2M) or LRP10 and the formula $2^{-\Delta \Delta C t}$ was used to calculate relative gene expression.

Table 1. Baseline anthropometric, biochemical and hormonal characteristics of study subjects.

\begin{tabular}{|c|c|c|c|}
\hline & T2DM & NonT2DM & $\mathbf{P}$ \\
\hline No. of subjects (male/female) & $11 / 0$ & $20 / 0$ & NR \\
\hline Age (years) & $62.0 \pm 2.0$ & $64.7 \pm 1.6$ & 0.307 \\
\hline Duration of operation $(h)$ & $5.2 \pm 0.18$ & $5.1 \pm 0.23$ & 0.457 \\
\hline Body mass index $\left(\mathrm{kg} / \mathrm{m}^{2}\right)$ & $31.3 \pm 1.46$ & $29.4 \pm 0.69$ & 0.322 \\
\hline Body surface area $\left(\mathrm{m}^{2}\right)$ & $1.98 \pm 0.07$ & $2.04 \pm 0.04$ & 0.448 \\
\hline Glucose (mmol/l) & $7.28 \pm 0.45$ & $5.84 \pm 0.18$ & 0.001 \\
\hline Insulin $(\mu I U / m l)$ & $29.9 \pm 4.9$ & $15.9 \pm 1.8$ & 0.014 \\
\hline$H O M A-I R$ index & $10.46 \pm 1.87$ & $4.20 \pm 0.58$ & 0.003 \\
\hline $\mathrm{HbAlc}(\mathrm{mmol} / \mathrm{mol} \mathrm{IFCC})$ & $51.7 \pm 2.9$ & $40.0 \pm 0.7$ & $<0.001$ \\
\hline$h s C R P(m g / l)$ & $0.260 \pm 0.085$ & $0.530 \pm 0.113$ & 0.048 \\
\hline Total cholesterol (mmol/l) & $3.85 \pm 0.19$ & $4.07 \pm 0.15$ & 0.312 \\
\hline HDL cholesterol (mmol/l) & $0.893 \pm 0.079$ & $0.989 \pm 0.054$ & 0.313 \\
\hline LDL cholesterol ( $\mathrm{mmol} / \mathrm{l})$ & $2.18 \pm 0.19$ & $2.42 \pm 0.14$ & 0.215 \\
\hline Triglycerides (mmol/l) & $1.77 \pm 0.19$ & $1.38 \pm 0.17$ & 0.240 \\
\hline$B N P(n g / l)$ & $398 \pm 241$ & $215 \pm 60$ & 0.620 \\
\hline$A-F A B P(n g / m l)$ & $31.1 \pm 5.1$ & $25.9 \pm 4.6$ & 0.175 \\
\hline
\end{tabular}

Values are mean \pm SEM. Statistical significance is from un-paired t-test or Mann-Whitney rank sum test, according to the normality of data distribution. T2DM, type 2 diabetes mellitus, NR, not relevant, BNP, brain natriuretic peptide 

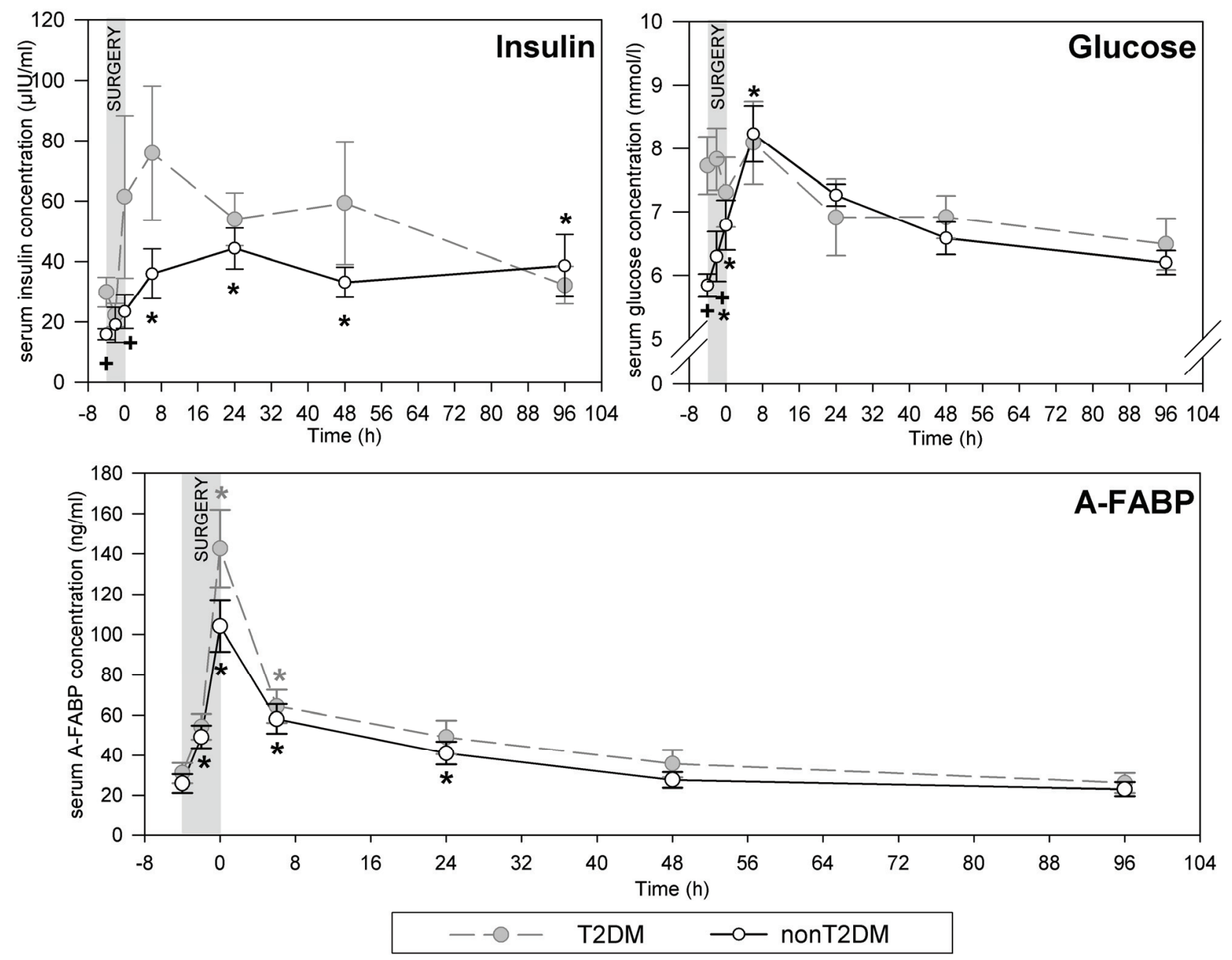

Fig. 1. Serum concentrations of insulin, glucose and A-FABP in cardiac surgery patients prior to initiation of anesthesia, prior to the start of extracorporeal circulation, upon completion of the surgery, and 6, 24, 48, and $96 \mathrm{~h}$ after the end of the surgery. Values are mean \pm SEM. The time of surgery completion was set as time zero. Statistical significance from one-way RM ANOVA and multiple comparisons versus control group test - Dunnett's method: $* p<0.05$ vs. prior to initiation of anesthesia; ${ }^{+} p<0.05$ vs. T2DM

\section{Statistical analysis}

Statistical analysis was performed on SigmaStat software (Jandel Scientific, San Rafael, CA, USA). The results are expressed as median (interquartile range) or mean \pm standard error of the mean (SEM). Normality of all data was assessed using the Kolmogorov-Smirnov test.

Changes of hormonal levels during perioperative and postoperative state were evaluated using one-way repeated measure analysis of variance (RM ANOVA) and multiple comparisons versus control group test Dunnett's method. Differences in gene expression between different tissues during operation were evaluated using one-way RM ANOVA and all pairwise multiple comparison procedures - Fisher LSD method. Differences between diabetic and non-diabetic subjects were evaluated using unpaired t-test or Mann-Whitney rank sum test, according to the normality of data. Correlations were analyzed using Spearman's or Pearson's correlation test, according to the normality of data. In all statistical tests $p$ values $<0.05$ were considered significant.

\section{Results}

\section{Clinical characteristics of study participants}

Clinical characteristics of study subjects are shown in Table 1. There were no differences between diabetic and non-diabetic patients with respect to age, body mass index (BMI), body surface area (BSA), lipid profile and BNP (brain natriuretic peptide). Diabetic subjects showed higher levels of baseline glucose, insulin, HOMA index and glycated hemoglobin, while their hsCRP values were slightly, but significantly, lower. 
Baseline A-FABP levels tended to be higher in patients with diabetes, although the difference did not reach statistical significance.

Serum glucose, hormonal and cytokine concentrations during and after surgery

In both study groups serum A-FABP concentrations during and after the surgical procedure followed the same pattern, peaking at the end of the surgery and returning to baseline levels 24 to $48 \mathrm{~h}$ after the end of the procedure (Fig. 1). No significant difference in A-FABP area under the curve (AUC) between the groups or its concentrations throughout the study period could be seen, although the maximum increase tended to be higher in the T2DM group (4.6-fold vs. 4.0 -fold, $\mathrm{p}=0.078)$. Serum glucose levels culminated $6 \mathrm{~h}$ after the end of the surgery and normalized $48 \mathrm{~h}$ thereafter with no difference between both groups except for the values at baseline and prior to the start of extracorporeal circulation, which were higher in diabetic subjects (Fig. 1). Serum insulin concentrations started to rise in both T2DM and nonT2DM subjects already during the operation reaching their peaks at 8 to $16 \mathrm{~h}$ after the start of the procedure and remaining significantly elevated for almost the whole study period. The increase was more pronounced in subjects with diabetes mellitus (Fig. 1). Serum CRP concentrations peaked in both groups at 24 to $48 \mathrm{~h}$ after the end of the surgery and returned to near normal values towards the end of the study period, while IL-6, IL-8 and MCP-1 reached their maximum levels immediately after the end of the surgical procedure. Again, no significant difference could be seen between T2DM and nonT2DM subjects at any of the studied timepoints (Fig. 2).
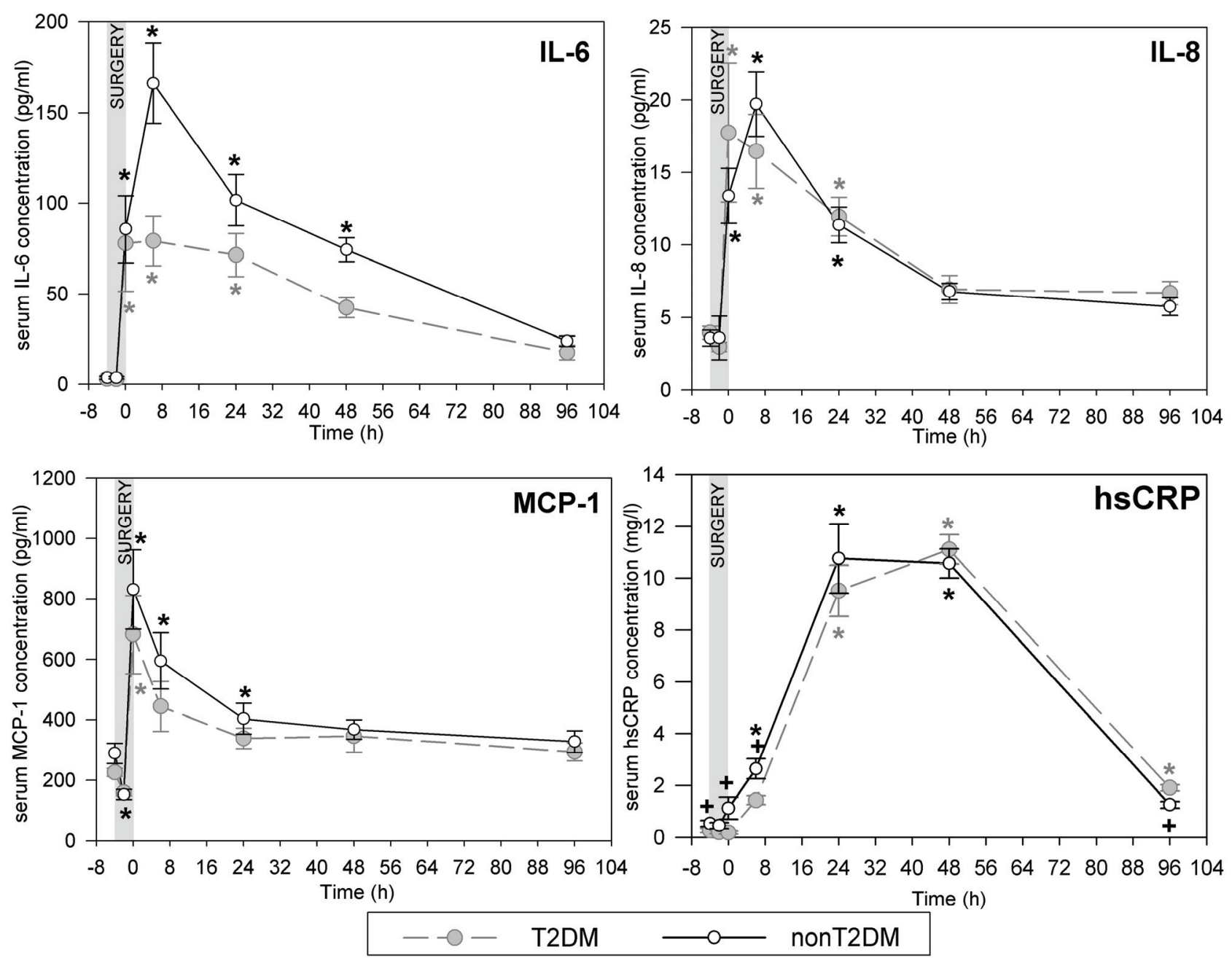

Fig. 2. Serum concentrations of IL-6, IL-8, MCP-1 and hSCRP in cardiac surgery patients prior to initiation of anesthesia, prior to the start of extracorporeal circulation, upon completion of the surgery and 6, 24, 48, and $96 \mathrm{~h}$ after the end of the surgery. Values are mean \pm SEM. The time of surgery completion was set as time zero. Statistical significance from one-way RM ANOVA and multiple comparisons versus control group test - Dunnett's method: $* p<0.05$ vs. prior to initiation of anesthesia; $+p<0.05$ vs. T2DM 

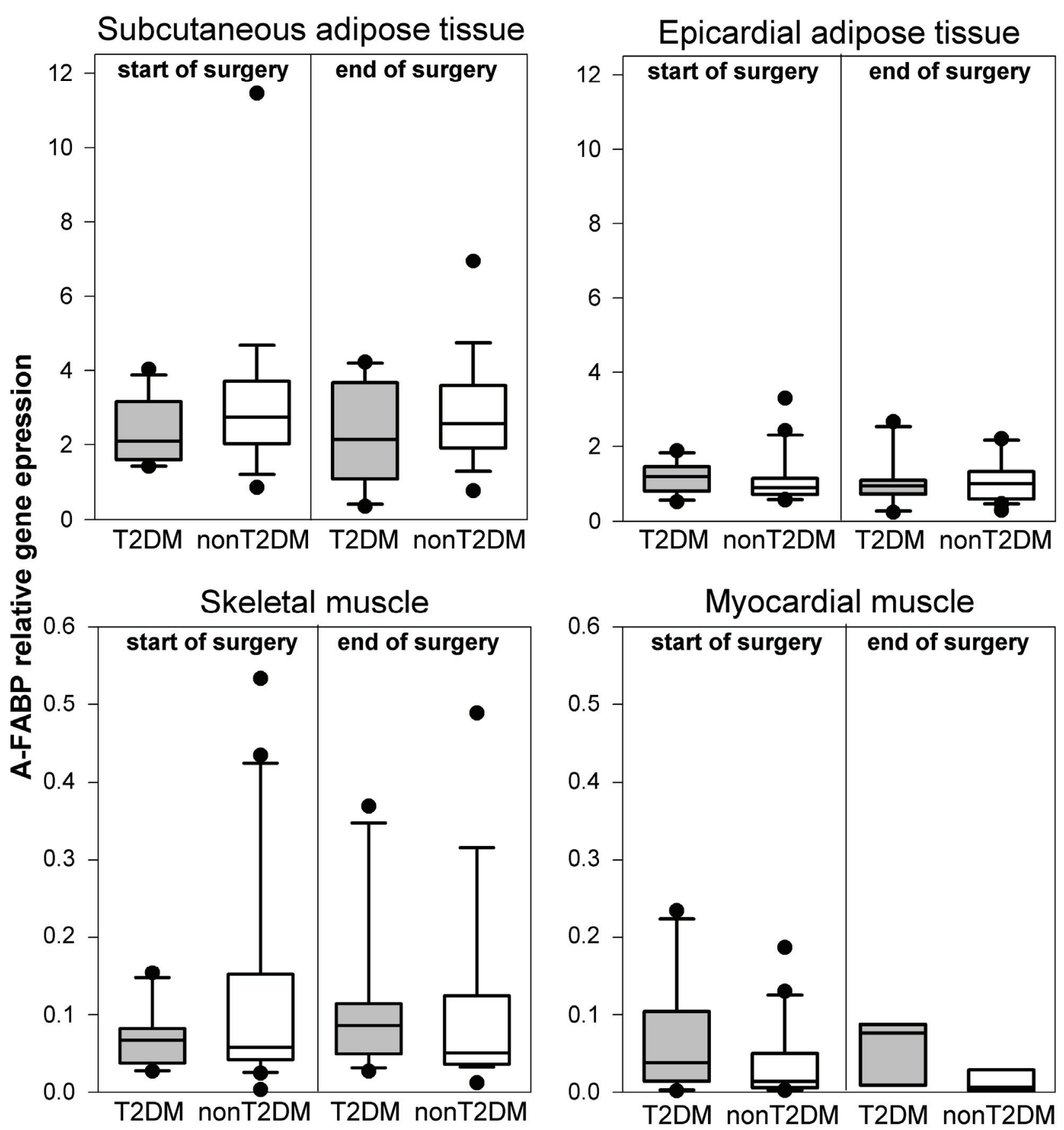

Fig. 3. Relative gene expression of A-FABP mRNA in subcutaneous adipose tissue, epicardial adipose tissue, skeletal muscle and myocardial muscle. Samples were taken at the start and prior to the end of surgery. Values are median and interquartile range.

A-FABP mRNA expression in adipose tissue, muscle and peripheral monocytes

No significant influence of the performed surgery on A-FABP mRNA expression was detected in either of the studied adipose or muscle tissues (Fig. 3). AFABP mRNA expression in epicardial adipose tissue was significantly lower than in subcutaneous adipose tissue both at the start and the end of the surgery, while it did not differ between skeletal and myocardial muscle at any of the studied timepoints (Fig. 3). In peripheral monocytes A-FABP mRNA expression showed a 4.9fold increase at the end of the surgery compared to baseline $(\mathrm{p}<0.05)$ followed by a significant decrease $24 \mathrm{~h}$ after the end of the surgery (Fig. 4). 


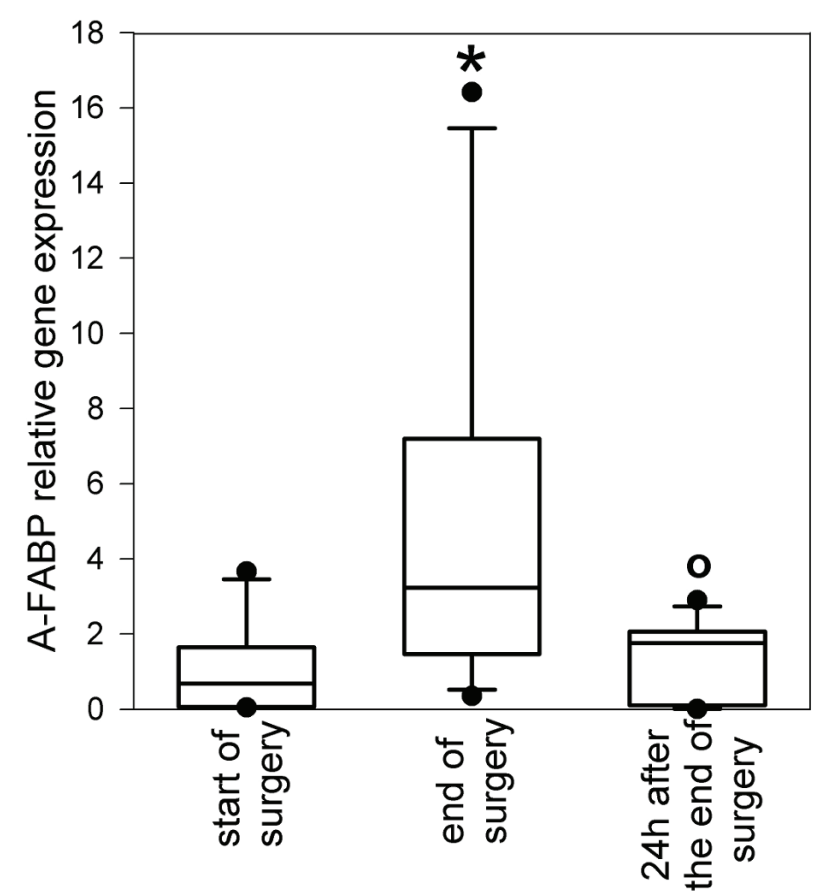

Fig. 4. Relative gene expression of A-FABP in isolated monocytes. Samples were taken at the start and end and $24 \mathrm{~h}$ after the end of surgery. Values are median and interquartile range. Results were normalized to the expression of LRP10. Statistical significance from one way RM ANOVA and all pairwise multiple comparison procedures (Dunn's method): $* \mathrm{p}<0.05$ vs. start of surgery; ${ }^{\circ} \mathrm{p}<0.05 \mathrm{vs}$. end of surgery

Relationship of A-FABP plasma levels and mRNA expression with anthropometric, biochemical, and hormonal parameters

In the whole study population serum A-FABP area under the curve correlated positively with baseline $\mathrm{HbA}_{1 \mathrm{c}}(\mathrm{R}=0.511 ; \mathrm{p}=0.006)$ and IL-8 area under the curve $(\mathrm{R}=0.701 ; \mathrm{p}<0.001)$. A-FABP mRNA expression in subcutaneous adipose tissue at the start of the surgery correlated positively with age $(\mathrm{R}=0.417 ; \mathrm{p}=0.025)$ and negatively with $\mathrm{BSA}(\mathrm{R}=-0.434 ; \mathrm{p}=0.017)$ and HOMA index $(\mathrm{R}=-0.425 ; \mathrm{p}=0.0305)$. In epicardial adipose tissue A-FABP mRNA expression showed positive correlation with HDL cholesterol $(\mathrm{R}=0.55 ; \mathrm{p}=0.0014)$, while correlating negatively only with BSA $(\mathrm{R}=-0.362$; $\mathrm{p}=0.046$ ). A-FABP mRNA expression in peripheral monocytes correlated positively with A-FABP serum concentrations $(\mathrm{R}=0.625 ; \mathrm{p}<0.001)$.

\section{Discussion}

Adipocyte fatty acid binding protein (A-FABP) is a recently introduced fat-derived protein involved in metabolic regulations, low-grade inflammation and the development of atherosclerosis. In the present study we show that its systemic levels and mRNA expression in circulating monocytes, albeit not in adipose or muscle tissue, are significantly increased by major cardiac surgery along with parameters of insulin resistance and systemic inflammation suggesting a possible role of AFABP in the development of perioperative insulin resistance and hyperglycemia of critically ill.

A growing number of epidemiological studies have demonstrated a positive relationship of A-FABP with metabolic derangements associated with increased adiposity in humans. Several cross-sectional studies have shown a positive correlation between circulating A-FABP and components of metabolic syndrome including obesity, insulin resistance and dyslipidemia (Tonjes et al. 2012, Xu et al. 2006, Cabré et al. 2008). In a recent prospective trial (Tso et al. 2007) elevated A-FABP levels predicted the development of type 2 diabetes mellitus independently of obesity and insulin resistance during a 10-year follow-up. Moreover, serum A-FABP levels were shown to be increased in patients with coronary artery disease (CAD) verified by coronary angiography (Doi et al. 2011) and were independently associated with cardiovascular morbidity and mortality in another trial on subjects with CAD (von Eynatten et al. 2012). In our study serum A-FABP reached relatively higher baseline levels in both groups as compared to previously published data (Doi et al. 2011). Interestingly, no significant difference between diabetic and nondiabetic individuals could be detected. These findings could most probably be explained by a high prevalence of other components of metabolic syndrome (obesity, dyslipidemia) and by the presence of ischemic heart disease in most of the subjects of both study groups.

Increased production of proinflammatory cytokines and adipokines is a well-established mechanism leading to the development of insulin resistance and hyperglycemia in patients undergoing major cardiac surgery (Kremen et al. 2006, Mazurek et al. 2003, Kotulak et al. 2011). Despite its potentially important role in the pathogenesis of type 2 diabetes mellitus and other obesity-related disorders, minimum data are available about the production, secretion and function of A-FABP during critical illness or surgeryrelated stress response. Here we demonstrate that systemic A-FABP levels rapidly increase (4- to 5-fold) in response to surgical stress with a subsequent decrease to almost basal levels $24 \mathrm{~h}$ after the procedure. This pattern shows a striking similarity to peri- and postoperative 
glycemic excursions and serum levels of proinflammatory cytokines assessed in the study (IL-6, IL-8, MCP-1) suggesting thus that circulating A-FABP might be an acute stress response protein as well as play a role in the development of perioperative insulin resistance and hyperglycemia of critically ill. Similarly to baseline levels, no difference could be observed in A-FABP concentrations between diabetic and non-diabetic subjects throughout the whole study period. This finding seems in line with the absence of difference in other studied factors between the 2 groups including blood glucose, insulin and proinflammatory cytokines indicating that metabolic control during and after the performed surgery reached comparable levels in both groups.

Epicardial adipose tissue has been previously identified as an important source of inflammatory mediators under basal conditions (Mazurek et al. 2003) and cardiac surgery increased mRNA expression of proinflammatory cytokines in both epicardial and subcutaneous adipose tissue (Kremen et al. 2006). In our previous study we demonstrated that circulating levels and epicardial adipose tissue mRNA expression of fibroblast growth factor 21 (FGF-21), which is another novel factor involved in metabolic regulations, were markedly increased by cardiac surgery (Kotulak et al. 2011). In the present trial baseline mRNA expression of A-FABP was significantly higher in subcutaneous than in epicardial adipose tissue. This is in accordance with findings by Fisher et al. (2001) who demonstrated that AFABP mRNA and protein production is elevated in subcutaneous as compared to visceral adipose depot in both lean and obese subjects. Surprisingly, no effect of cardiac surgery could be seen on mRNA expression of AFABP in either of the studied adipose tissue pools. As circulating A-FABP levels peaked at the same time the second tissue sample was taken, these findings suggest that neither subcutaneous nor visceral (epicardial) adipose tissue is the primary source of elevated serum AFABP during cardiac surgery and that, in contrast to e.g. heart-type fatty acid binding protein (H-FABP), another type of FABP which was shown to increase in response to operation-related injury to the heart muscle, A-FABP is not a significant marker of local tissue damage. This was further confirmed by the results of A-FABP mRNA expression in skeletal and heart muscle which was considerably lower than in adipose tissue and was also unaffected by the performed surgery.

Although originally A-FABP has been considered adipocyte specific, macrophages were shown to be other potentially important source of A-FABP. In experimental models on primary human monocytes and monocytic cell lines A-FABP mRNA expression became evident after stimulation with both natural and synthetic peroxisome-proliferator activated receptor gamma (PPAR $\gamma$ ) agonists (Pelton et al. 1999). In macrophages lacking A-FABP $\left(A-F A B P^{-/-}\right)$significant reduction in the expression of several inflammatory cytokines was described (Makowski et al. 2005). Moreover, after exposition to modified lipoproteins $A-F A B P^{-/-}$ macrophages showed reduced inflammatory cytokine production and ability to accumulate cholesterol (Makowski et al. 2005). Apolipoprotein E (ApoE) deficient and $A-F A B P^{-/-}$mice were protected against the development of atherosclerosis, while adipocyte $A$ $F A B P^{+/+}, A p o e^{-/-}$and macrophage $A-F A B P^{-/-}$mice showed similar reduction on atherosclerosis compared to total A-FABP deficient mice (Makowski et al. 2001). In a human study on patients undergoing carotid endarterectomy, macrophage A-FABP mRNA expression was increased in unstable carotid plaques (Agardh et al. 2011). Another recent study on patients with rheumatoid arthritis demonstrated increased A-FABP expression in several types of immune cells including synovial macrophages and B-cells (Andrés Cerezo et al. 2013). Taken together, experimental animal and human data strongly indicate a possible role of macrophage A-FABP in atherogenic processes and inflammation. In the present study we analyzed mRNA expression of A-FABP in peripheral monocytes, which are considered circulating precursors of macrophages (Mraz et al. 2011). Strikingly, we found a substantial increase in A-FABP expression at the end of the procedure which practically normalized after $24 \mathrm{~h}$. This early peak followed by a relatively rapid normalization almost duplicates the peri- and postoperative excursions of serum A-FABP suggesting that peripheral monocytes might be one of the primary sources of increased circulating A-FABP under surgical stress. Moreover, peripheral monocytes have previously been shown to be important mediators of low-grade inflammation. Considering the role of A-FABP in the production of proinflammatory cytokines and activation of endoplasmatic reticulum stress in macrophages (Erbay et al. 2009), up-regulation of A-FABP mRNA in monocytes might substantially increase their proinflammatory state, which in turn can potentially contribute to the development of surgery-related hyperglycemia and insulin resistance.

A recent experimental study demonstrated the 
existence of direct effects of A-FABP on cardiomyocytes resulting in acute inhibition of their contraction. The negative inotropic effect was dependent on A-FABP concentration (Lamounier-Zepter et al. 2009). Thus elevated levels of circulating or locally produced AFABP might, at least theoretically, influence the development of heart dysfunction. To test this hypothesis we analyzed the relationship between circulating AFABP and serum brain natriuretic peptide (BNP), a marker of heart failure. However, we were not able to find any significant relationship between circulating BNP and serum A-FABP in the whole cohort as well as in either of the subgroups. Further in vivo studies are needed to evaluate the possible influence of A-FABP on heart function in various patient populations.

We are aware of several limitations of our study. The relatively small number of study subjects and high interindividual variability of some of the measured parameters might have been a potential source of bias throughout the statistical analysis. Full-scale studies on larger populations with a more diverse spectrum of critical conditions involving also protein analysis of investigated tissues should be the aim of future research on this topic.

We have demonstrated that irrespectively of the presence of diabetes mellitus elective cardiac surgery induces significant increase in plasma A-FABP that corresponds with hyperglycemia, hyperinsulinemia and proinflammatory response. Peripheral monocytes, and not adipose tissue, seem to be one of the main contributors to this increase. Our data suggest that circulating A-FABP might be involved in acute perioperative stress response with a potential role in the development of perioperative insulin resistance and hyperglycemia of critically ill.

\section{Conflict of Interest}

There is no conflict of interest.

\section{Acknowledgements}

This work was supported by MHCR RVO-VFN 64165 and IGA NT13299-4 to MH.

\section{References}

AGARDH HE, FOLKERSEN L, EKSTRAND J, MARCUS D, SWEDENBORG J, HEDIN U, GABRIELSEN A, PAULSSON-BERNE G: Expression of fatty acid-binding protein 4/aP2 is correlated with plaque instability in carotid atherosclerosis. J Intern Med 269: 200-210, 2011.

ANDRÉS CEREZO L, KUKLOVÁ M, HULEJOVÁ H, VERNEROVÁ Z, PEŠÁKOVÁ V, PECHA O, VEIGL D, HALUZÍK M, PAVELKA K, VENCOVSKÝ J, SENOLT L: The level of fatty acid-binding protein 4, a novel adipokine, is increased in rheumatoid arthritis and correlates with serum cholesterol levels. Cytokine 64: 441447, 2013.

BAO Y, LU Z, ZHOU M, LI H, WANG Y, GAO M, WEI M, JIA W: Serum levels of adipocyte fatty acid binding protein are associated with the severity of coronary artery disease in chinese women. PLoS One 28: 19115, 2011.

BAXA CA, SHA RS, BUELT MK, SMITH AJ, MATARESE V, CHINANDER LL, BOUNDY KL, BERNLOHR DA: Human adipocyte lipid-binding protein purification of the protein and cloning of its complementary DNA. Biochemistry 28: 8683-8690, 1989.

BLAHA J, KOPECKY P, MATIAS M, HOVORKA R, KUNSTYR J, KOTULAK T, LIPS M, RUBES D, STRITESKY M, LINDNER J, SEMRAD M, HALUZIK M: Comparison of three protocols for tight glycemic control in cardiac surgery patients. Diabetes Care 32: 757-761, 2009.

BOORD JB, FAZIO S, LINTON MF: Cytoplasmatic fatty acid binding proteins: emerging roles in metabolism and atherosclerosis. Curr Opin Lipidol 13: 141-147, 2002.

CABRÉ A, LÁZARO I, GIRONA J, MANZANARES JM, MARIMÓN F, PLANA N, HERAS M, MASANA L: Plasma fatty acid binding protein 4 is associated with atherogenic dyslipidemia in diabetes. $J$ Lipid Res 49 : 1746-1751, 2008.

DOI M, MIYOSHI T, HIROHATA S, NAKAMURA K, USUI S, TAKEDA K, IWAMOTO M, KUSACHI S, KUSANO K, ITO H: Association of increased plasma adipocyte fatty acid-binding protein with coronary artery disease in non-elderly men. Cardiovasc Diabetol 10: 44, 2011. 
ERBAY E, BABAEV VR, MAYERS JR, MAKOWSKI L, CHARLES KN, SNITOW ME, FAZIO S, WIEST MM, WATKINS SM, LINTON MF, HOTAMISLIGIL GS: Reducing endoplasmic reticulum stress through a macrophage lipid chaperone alleviates atherosclerosis. Nat Med 15: 1383-1391, 2009.

FINFER S, CHITTOCK DR, SU SY, BLAIR D, FOSTER D, DHINGRA V, BELLOMO R, COOK D, DODEK P, HENDERSON WR, HÉBERT PC, HERITIER S, HEYLAND DK, MCARTHUR C, MCDONALD E, MITCHELL I, MYBURGH JA, NORTON R, POTTER J, ROBINSON BG, RONCO JJ: Intensive versus conventional glucose control in critically ill patients. $N$ Engl J Med 360: 1283-1297, 2009.

FISHER RM, ERIKSSON P, HOFFSTEDT J, HOTAMISLIGIL GS, THÖRNE A, RYDÉN M, HAMSTEN A, ARNER P: Fatty acid binding protein expression in different adipose tissue depots from lean and obese individuals. Diabetologia 44: 1268-1273, 2001.

FURUHASHI M, TUNCMAN G, GÖRGÜN CZ, MAKOWSKI L, ATSUMI G, VAILLANCOURT E, KONO K, BABAEV VR, FAZIO S, LINTON MF, SULSKY R, ROBL JA, PARKER RA, HOTAMISLIGIL GS: Treatment of diabetes and atherosclerosis by inhibiting fatty-acid-binding protein aP2. Nature 447: 959-965, 2007.

FURUHASHI M, FUCHO R, GÖRGÜN CZ, TUNCMAN G, CAO H, HOTAMISLIGIL GS: Adipocyte/macrophage fatty acid-binding proteins contribute to metabolic deterioration trough actions in both macrophages and adipocytes in mice. J Clin Invest 118: 2640-2650, 2008.

HALUZÍKOVÁ D, DOSTÁLOVÁ I, KAVÁLKOVÁ P, ROUBÍCEK T, MRÁZ M, PAPEZOVÁ H, HALUZÍK M: Serum concentrations of adipocyte fatty acid binding protein in patients with anorexia nervosa. Physiol Res 58: 577-581, 2009.

HOTAMISLIGIL GS, JOHNSON RS, DISTEL RJ, ELLIS R, PAPAIOANNOU VE, SPIEGELMAN BM: Uncoupling of obesity from insulin resistance trough a targeted mutation in aP2, the adipocyte fatty acid binding protein. Science 274: 1377-1379, 1996.

HUNT CR, RO JH, DOBSON DE, MIN HY, SPIEGELMAN BM: Adipocyte P2 gene: developmental expression and homology of 5'-flanking sequences among fat cell-specific genes. Proc Natl Acad Sci USA 83: 3786-3790, 1986.

KOTULÁK T, DRÁPALOVÁ J, KOPECKÝ P, LACINOVÁ Z, KRAMÁŘ P, ŘÍHA H, NETUKA I, MALÝ J, HOUSA D, BLÁHA J, SVAČINA Š, HALUZÍK M: Increased circulating and epicardial adipose tissue mRNA expression of fibroblast growth factor-21 after cardiac surgery: possible role in postoperative inflammatory response and insulin resistance. Physiol Res 60: 757-767, 2011.

KREMEN J, DOLINKOVA M, KRAJICKOVA J, BLAHA J, ANDERLOVA K, LACINOVA Z, HALUZIKOVA D, BOSANSKA L, VOKURKA M, SVACINA S, HALUZIK M: Increased subcutaneous and epicardial adipose tissue production of proinflammatory cytokines in cardiac surgery patients: possible role in postoperative insulin resistance. J Clin Endocrinol Metab 91: 4620-4627, 2006.

LAMOUNIER-ZEPTER V, LOOK C, ALVAREZ J, CHRIST T, RAVENS U, SCHUNCK WH, EHRHARTBORNSTEIN M, BORNSTEIN SR, MORANO I: Adipocyte fatty acid-binding protein suppresses cardiomyocyte contraction: a new link between obesity and heart disease. Circ Res 105: 326-334, 2009.

MAKOWSKI L, BOORD JB, MAEDA K, BABAEV VR, UYSAL KT, MORGAN MA, PARKER RA, SUTTLES J, FAZIO S, HOTAMISLIGIL GS, LINTON MF: Lack of macrophage fatty-acid-binding protein aP2 protects mice deficient in apolipoprotein E against atherosclerosis. Nat Med 7: 699-705, 2001.

MAKOWSKI L, BRITTINGHAM KC, REYNOLDS JM, SUTTLES J, HOTAMISLIGIL GS: The fatty acid-binding protein, aP2, coordinates macrophage cholesterol trafficking and inflammatory activity. Macrophage expression of aP2 impacts peroxisome proliferator-activated receptor $\gamma$ and IкB kinase activities. $J$ Biol Chem 280: 12888-12895, 2005.

MAZUREK T, ZHANG L, ZALEWSKI A, MANNION JD, DIEHL JT, ARAFAT H, SAROV-BLAT L, O'BRIEN S, KEIPER EA, JOHNSON AG, MARTIN J, GOLDSTEIN BJ, SHI Y: Human epicardial adipose tissue is a source of inflammatory mediators. Circulation 108: 2460-2466, 2003. 
MRAZ M, LACINOVA Z, DRAPALOVA J, HALUZIKOVA D, HORINEK A, MATOULEK M, TRACHTA P, KAVALKOVA P, SVACINA S, HALUZIK M: The effect of very-low-calorie diet on mRNA expression of inflammation-related genes in subcutaneous adipose tissue and peripheral monocytes of obese patients with type 2 diabetes mellitus, $J$ Clin Endocrinol Metab 96: E606-E613, 2011.

PELTON PD, ZHOU L, DEMAREST KT, BURRIS TP: PPARgamma activation induces the expression of the adipocyte fatty acid binding protein gene in human monocytes. Biochem Biophys Res Commun 261: 456-458, 1999.

TÖNJES A, KRALISCH S, LÖSSNER U, KOVACS P, BLÜHER M, STUMVOLL M, FASSHAUER M: Metabolic and genetic predictors of circulating adipocyte fatty acid-binding protein. Int J Obes (Lond) 36: 766-773, 2012.

TSO AW, XU A, SHAM PC, WAT NM, WANG Y, FONG CH, CHEUNG BM, JANUS ED, LAM KS: Serum adipocyte fatty acid binding protein as a new biomarker predicting the development of type 2 diabetes: a 10year prospective study in a Chinese cohort. Diabetes Care 30: 2667-2672, 2007.

TUNCMAN G, ERBAY E, HOM X, DE VIVO I, CAMPOS H, RIMM EB, HOTAMISLIGIL GS: A genetic variant at the fatty acid-binding protein aP2 locus reduces the risk for hypertriglyceridemia, type 2 diabetes, and cardiovascular disease. Proc Natl Acad Sci U S A 103: 6970-6975, 2006.

UYSAL KT, SCHEJA L, WIESBROCK SM, BONNER-WEIR S, HOTAMISLIGIL GS: Improved glucose and lipid metabolism in genetically obese mice lacking aP2. Endocrinology 141: 3388-3396, 2000.

VAN DEN BERGHE G: Endocrinology in intensive care medicine: new insights and therapeutic consequences. Verh $K$ Acad Geneeskd Belg 64: 167-187, 2002.

VAN DEN BERGHE G, WOUTERS P, WEEKERS F, VERWAEST C, BRUYNINCKX F, SCHETZ M, VLASSELAERS D, FERDINANDE P, LAUWERS P, BOUILLON R: Intensive insulin therapy in the critically ill patients. $N$ Engl J Med 345: 1359-1367, 2001.

VON EYNATTEN M, BREITLING LP, ROOS M, BAUMANN M, ROTHENBACHER D, BRENNER H: Circulating adipocyte fatty acid-binding protein levels and cardiovascular morbidity and mortality in patients with coronary heart disease: a 10-year prospective study. Arterioscler Thromb Vasc Biol 32: 2327-2335, 2012.

XU A, WANG Y, XU JY, STEJSKAL D, TAM S, ZHANG J, WAT NM, WONG WK, LAM KS: Adipocyte fatty acidbinding protein is a plasma biomarker closely associated with obesity and metabolic syndrome. Clin Chem $\mathbf{5 2}$ : 405-413, 2006.

XU A, TSO AW, CHEUNG BM, WANG Y, WAT NM, FONG CH, YEUNG DC, JANUS ED, SHAM PC, LAM KS: Circulating adipocyte-fatty acid binding protein levels predict the development of the metabolic syndrome: a 5years prospective study. Circulation 115: 1537-1543, 2007. 